\title{
JOINT ENTERPRISE AND SECONDARY LIABILITY ${ }^{1}$
}

Professor Sir John Smith CBE, QC, FBA:

\section{Emeritus Professor in Residence, University of Nottingham}

There are two ways in which a person may be guilty of a crime. Either -

(i) he committed it; or

(ii) he aided, abetted, counselled or procured another to commit it.

The criminal is either a principal or he is "a secondary party" - a term coined by Glanville Williams in the first edition of his Criminal Law: The General Part in 1953, to comprehend aiders, abettors, counsellors and procurers.

Generally it does not matter which he is because, if he is a secondary party, he may, under section 8 of the Accessories and Abettors Act 1861 (or its Northern Irish equivalent), be indicted, tried and punished as a principal offender.

\section{Principals}

A principal is one who, by his own act or unlawful omission, causes the actus reus of the offence. For this purpose, A who procures B to commit the crime does not cause it. The man who engages a contract killer to murder his wife is a secondary party, not the principal offender. The reason is that a fully voluntary intervening act by a responsible person - in this case, the contract killer - breaks the chain of causation. For this reason, I have great difficulty with a recent case, Kennedy. ${ }^{2}$ Kennedy $[\mathrm{K}]$ handed to Bosque $[\mathrm{B}]$ a syringe which $\mathrm{K}$ had prepared containing heroin and water. B, being aware of the contents of the syringe, injected himself and consequently died. It was held that $\mathrm{K}$ was guilty of manslaughter because he "assisted or encouraged" B to do the fatal act. But it was B's own act which caused his death. Death was not, in law, caused by K. B killed himself. There was a crime of self-murder - felo de se - at common law ; and a person could be guilty of murder by abetting suicide; but there has never been an offence of self-manslaughter. Assisting and encouraging another to commit a crime is secondary participation; but the act which $\mathrm{K}$ assisted $\mathrm{B}$ to commit was certainly not the crime of manslaughter, and probably not a crime at all. The court saw no reason why $\mathrm{K}$ should not have been convicted of administering a noxious thing to, or causing it to be taken by, another, contrary to section 23 of the Offences against the Person Act 1861 . 1 see a very good reason why he should not be so convicted - simply that $\mathrm{K}$ did not administer the noxious thing to another, or cause it to be taken by him, as the Act requires. B administered it to himself and that was not the offence.

\section{Joint principals}

There may be more than one cause of an actus reus and more than one causer. Each causer is a principal. A and B both stab X who dies from the combined effect of the wounds A and B together plant a bomb which goes off and kills X. Each is liable for his own act, not only because he has

1 The Annual Address for 1999 to the judiciary of Northern Ireland, February 16, 1999.

2 [1999] Crim LR 65 


\section{Northern Ireland Legal Quarterly [Vol. 50, No. 2]}

aided and abetted the act of another, though he may have done that as well. Each is liable in accordance with the mens rea with which he caused the actus reus. To take a hypothetical case based on McPhillips ${ }^{3}$ (a conspiracy case), suppose that, in the bomb example, B intends (and believes that $\mathrm{A}$ intends) that ample warning will be given to allow the area to be cleared, but A intends that no warning be given. The bomb goes off prematurely and kills V. A is prima facie guilty of murder, B of manslaughter. There is only one act of planting the bomb, but each of them does that act; and does it with a mens rea different from that of his co-actor. There is one death; but there are two principals and two distinct offences of homicide.

\section{Parties to a joint enterprise who are present: are they principals?}

Recently a theory has emerged that all parties to a joint enterprise who are present at the commission of the crime are, in the old terminology of felonies, all principals in the first degree, not secondary parties or accessories. This notion, though not expressed, probably lies at the root of a Law Commission recommendation that the whole law of aiding, abetting, counselling and procuring be abolished - section 8 of the 1861 Act would be repealed - and replaced by two substantive offences of assisting and encouraging crime, while - possibly, at least - leaving the common law of joint enterprise intact. Joint enterprise liability, according to this view, is something different from secondary liability. The Law Commission's opinion seemed to me to be misconceived. I do not believe it is possible to abolish secondary participation and leave the law of joint enterprise in existence. But the Commission's opinion seems to have been impliedly endorsed by Hobhouse LJ, now Lord Hobhouse, on more than one occasion. As a similar view has recently been taken by the greatly respected High Court of Australia in Osland $v R^{4}$ it is a matter which I will pursue a little further.

In Osland a woman and her son, David, agreed to kill her husband, the boy's stepfather. They dug a grave in preparation. They administered sedatives to the woman's husband and, when he was asleep, David, in her presence, killed him by a blow with an iron pipe. That seems a very clear case of murder by the son, aided and abetted by his mother. The jury convicted her of murder but they disagreed about David. We do not know why, of course, but both defendants had raised, what seem to me, very optimistic defences of provocation and self-defence. So the difficulty was that there was no proven murder for the woman to aid and abet. The conviction was upheld by a majority of five to two. McHugh LJ said that the law was accurately stated in an Australian text book, Brett, Waller and Williams: ${ }^{5}$

"[Even] if only one participant performed the acts constituting the crime, each will be guilty as principals [sic] in the first degree [McHugh J's emphasis] if the acts were performed in the presence of all and pursuant to

3 [1990] BNIL, Smith and Hogan, Cases and Materials (6th ed, 1996) 353.

[1998] 73 ALJR 173.

$58^{\text {th }}$ ed, $1997, \mathrm{p}$ 467. The authority cited is a summing-up to a jury by Smith J: Lowery and King (No 2) [1972]VR 560. It is, with respect, an excellent summing up, telling the jury just what they need to know in such a case. But it does not purport to be a complete exposition of the law. All that the learned judge said was that the parties were all equally guilty. Of course they were, as are all secondary parties. He did not say that parties acting in concert were "principals in the first degree". 
a preconceived plan. In that case, the parties are said to be acting in concert."

Alternatively it was suggested that the woman had contributed to causing the death, by her participation, particularly administering the sedative something done by the woman to the deceased, which directly contributed to his death. I would have no difficulty with the second reason. ${ }^{6}$ It is the first which concerns me because it appears to, say, be similar to that of Lord Hobhouse in Stewart and Schofield. (1995). ${ }^{7}$ The appellants and Lambert [L] set out to rob a shopkeeper. L was armed with a scaffolding bar. He and Stewart went into the shop while Schofield kept watch outside. L killed the shopkeeper by blows with the bar. He was convicted of murder and the appellants of manslaughter. In the light of the summing-up, the verdicts imply that the appellants foresaw that L might cause some injury but did not foresee that the bar would, or might, be used with intent to cause serious injury. They relied, inter alia, on Dunbar. ${ }^{8}$ There, the prosecution's case (which was not accepted by the jury)was that Dunbar hired X to kill Y. X killed Y and the jury convicted X of murder, but acquitted Dunbar of murder and convicted her of manslaughter. As the Court of Appeal said, the jury must have found that Dunbar contemplated the use by $X$ of violence short of grievous bodily harm but that $X$ went beyond that, and acted with intent to cause at least grievous bodily harm. Dunbar's conviction of manslaughter was quashed. If she was a party only to an agreement to inflict some harm less than grievous bodily harm, the killing with intent to do grievous bodily harm was not within the ambit of the agreement and she was guilty of neither murder nor manslaughter. She was not responsible for that unforeseen act. In Stewart and Schofield Hobhouse LJ, dismissing the appeals and disapproving of a passage in Smith and Hogan and two of my notes in the Criminal Law Review, said that Dunbar probably should not be categorised as a case of joint enterprise at all. He distinguished a party to a joint enterprise from, as he put it, a "mere aider and abettor, etc.," or secondary party:

"In contrast where the allegation is joint enterprise, the allegation is that one party participated in the criminal act of another."

I criticised that ruling, asking how do you "participate in the criminal act of another" except by assisting or encouraging that act? - that is, by aiding, abetting, counselling or procuring it. Suppose that A, B and C agree, and set out, to rape V. A and $B$ hold her down while $C$ has intercourse with her. How can A and B participate in the act of sexual intercourse except by assisting or encouraging $\mathrm{C}$ to do it? Of course they are all guilty equally guilty - of rape; but are we really required to pretend that $\mathrm{A}$ and $\mathrm{B}$ had intercourse? It is no different in principle if $A, B$ and $C$ set out to kill and $\mathrm{C}$ fires the fatal shot. How do you participate in the act of pointing the gun and pulling the trigger - except by assisting or encouraging another to do it?

It seems there is only one possible ground of distinction between Dunbar and Stewart - Dunbar was not present, Stewart was. But the Court of Appeal had already decided in $\operatorname{Rook}^{9}$ that the same principles apply to an absent secondary party as to one who is present. Rook was not cited to the Court in Stewart and Schofield and I ventured to suggest that Hobhouse LJ

\footnotetext{
6 Cf S v Masilela 1968 (2) SA (AD)

7 [1995] 3 All ER 159.

8 [1988] Crim LR 693.

9 [1993] 2 All ER 955.
} 


\section{Northern Ireland Legal Quarterly [Vol. 50, No. 2]}

would have decided differently if Rook had been cited. I was wrong again.

Hobhouse LJ returned to the subject in a civil action - Generale Bank Nederland NV v Export Credits Guarantee Department ${ }^{\overline{0}}$ [1998] 1 Lloyd's Rep at pp 42-44. He relied particularly on Macklin ${ }^{11}$ (1838) where a group of persons attacked a constable, some with sticks, some by throwing stones and some with their fists. Alderson B directed the jury that it is a principle of law that: “...if several persons act together in pursuance of a common intent, every act in furtherance of such intent by each of them is, in law done by all." This formulation of the law goes back at least to the early 17 th century. Hale, Pleas of the Crown, 1, 463 refers to a case where one of a number of rioters killed a constable's assistant and it was unanimously agreed at the King's Bench -

"That, altho the indictment were, that B gave the stroke, and the rest were present aiding and abetting, tho in truth $C$ gave the stroke, or that it did not appear on the evidence which of them gave the stroke, but only that it was given by one of the rioters, yet the evidence was sufficient to maintain the indictment, for in law it was the stroke of all that party according to the resolution in Mackally's case. 9 Co Rep 67 b."

\section{Hobhouse LJ went on}

"Thus persons who participate in a criminal joint enterprise are, through the attribution to them of the actus reus, ${ }^{12}$ in reality joint principals with the primary actor. However since the primary actor has himself committed a criminal offence, there is a tendency to treat him alone as the principal and all the others as mere accessories."

This is not merely "a tendency." It is ancient law. Parties who were present at the commission of a felony were originally described as "accessories at the fact." Only the actual perpetrator was the principal. The rest were accessories, before, at, or after the fact, as the case may be. The later change of name to principal in the second degree made no difference of substance. ${ }^{13}$ The liability of the aider and abettor present at the commission of the crime continued to derive from that of the principal it was in the nature of accessory, or, as Glanville Williams has it, secondary, liability. There is abundant and consistent authority for this in the writers of authority. I cite only the great Fitzjames Stephen writing, in the last edition under his own hand (1886), of his Digest of the Criminal Law, Art 38, headed "Common Purpose."

"When several persons take part in the execution of a common criminal purpose, each is a principal in the second degree, in respect of every crime committed by any one of them in the execution of that purpose."

101 Lloyd's Rep at 42-44.

11 (1838) 2 Lewin CC 225; 168 ER 1136.

12 Author's italics.

13 "Where two or more are brought to justice for the same felony, they are considered in the light of principals in the first degree, as having actually and with their own hands committed the fact; or of principals in the second degree, as having been present aiding and abetting at the commission of it; or of accessories before or after the fact: Foster, Crown Law, 3rd ed. 1809, 347. (My italics). See to the same effect Russell on Crime (3rd ed., 1843) 26. 
Hobhouse LJ's "attribution" to A and B of the actus reus, in fact committed only by $\mathrm{C}$, seems to mean that we have to pretend that $\mathrm{A}$ and $\mathrm{B}$ killed V, which they did not. ${ }^{14}$ It is another way of saying, as the High Court of Australia did in Osland, that they are all principals in the first degree. This is a fiction and fictions should have, and I believe do not have, any place in modern criminal law. Of course, responsibility for the victim's death is attributed to A and B - because they "aided, abetted counselled or procured it" - but that is entirely different and quite proper. That is the simple law which, in my opinion, was applied in Macklin.

In DPP for Northern Ireland $v$ Maxwell ${ }^{15}$ the House of Lords reminded lawyers that the stroke of one is not in fact, or in law, the stroke of all the parties to an offence, and that, whenever possible, the actual mode of participation of each should be specified in the indictment. ${ }^{16}$

The true position in cases like Macklin, it is submitted, was recently expounded by Beldam LJ: ${ }^{17}$ when a group of persons make an attack on another, the only reasonable inference may be that they have the common purpose of harming him. Each encourages or assists the others by his participation. If an injury is caused, anyone who caused it is liable, but all of them, whether principals or not, are liable to conviction because each assisted or encouraged the others. Some may be both principals and accessories, some only accessories. It does not matter. So long as the jury are satisfied that a particular defendant was one or the other, they must convict him. No fictitious "attribution" is involved or needed.

\section{Attribution to a party of the actus reus, or responsibility for the actus reus?}

Does it matter whether the act, or only responsibility for the act, is attributed to a party in a joint enterprise? It may, where A has caused the actus reus with an intent materially different from, and more serious than, any foreseen by B. B is not liable for that more serious offence because he lacks the necessary mens rea. But, if B were to be deemed to have committed the actus reus, to have done the act with his own hand, then he might be convicted as a principal of the lesser offence for which he had the mens rea. In addition to the undesirability of fictions, a powerful objection to this theory is that, because $\mathrm{P}$ acted with a fundamentally different intent, the act itself is fundamentally different. The facts of Murtagh and Kenned ${ }^{18}$ provide a useful illustration. $\mathrm{M}$ and $\mathrm{K}$, engaged in a feud with another gang, were charged with murder by running down $\mathrm{X}$ in a car in which $\mathrm{M}$ was the driver and $\mathrm{K}$ the passenger. The jury were properly directed that driving a car at a person with intent to kill him or cause him serious injury would be murder but that, if the intent was to drive near to X, so as to terrorise him, it would be manslaughter. The jury convicted $\mathrm{M}$ of murder and $\mathrm{K}$ of manslaughter. Both convictions were

14 In DuCros v Lambourne (1906) 21 Cox CC 311, 316 Darling J is reported to have said of the owner of a car sitting beside the driver who was exceeding the speed limit, "It seems to me a misuse of language to say he was not driving the motor-car." But he wisely had second thoughts and this sentence does not appear in his revised judgment in [1907] KB 40, 46. The gross misuse of language would be to describe the passenger as the driver.

15 [1978] 3 All ER 1140.

16 This advice has been "universally ignored," according to the Court of Appeal in Taylor [1998] Crim LR 582.

17 Greatrex and Bates [1999] 1 Cr App R 126. Beldam LJ made a similar analysis in Uddin [1999] 2 All ER 744 at 751.

18 (1955) 39 Cr App R 72. 
quashed on other grounds which are irrelevant for present purposes. The verdicts, however, implied that $M$, the driver, intended to run $X$ down but that $\mathrm{K}$ intended only that the car be driven close so as to frighten him. Surely these are fundamentally different acts. $\mathrm{M}$ and $\mathrm{K}$ were clearly engaged in an unlawful joint enterprise in a feud with $\mathrm{V}$; but how can we attribute M's act of running $V$ down to $K$ in view of the implicit finding that $\mathrm{K}$ did not intend and no finding that he foresaw any such act? ${ }^{19}$ In the bizarre South African case of Robinson, ${ }^{20} \mathrm{X}$ had agreed with $\mathrm{A}$ and $\mathrm{B}$ that he must die, apparently murdered, in order to solve their pressing financial problems by getting the insurance monies. A was to shoot $\mathrm{X}$ in the back of the head. $A$ and $\mathrm{B}$ had the common purpose of committing murder. At the last minute, $\mathrm{X}$ withdrew his consent to die. A, in B's, absence shot him in the back of the head. B, in the opinion of the majority of the court, was not liable for a killing which was fundamentally different from that contemplated.

Lord Hobhouse's theory and the decision in Osland are, I suggest, objectionable on two grounds. First, they involve a fiction, and fictions should have no place in modern criminal law; and, second, they would reintroduce the distinction between presence and absence which I thought we had got rid of in 1967, with the abolition of the law relating to felonies. It is a primitive distinction, with no moral content, which we can well do without.

The theory is more plausible (but equally unsound) where the physical act done by $\mathrm{A}$ is that contemplated by $\mathrm{B}$ but $\mathrm{A}$ has the mens rea of a more serious offence, perhaps because he knows more about the circumstances than B. A and B agree to inflict a slight wound to V. A knows, but B does not, that $\mathrm{V}$ is a haemophiliac. A inflicts the slight wound and $\mathrm{V}$ bleeds to death. But even here, scratching a haemophiliac is a fundamentally different act from scratching a person not so afflicted. Shooting a consenting person in the back of the head is fundamentally different from shooting a non-consenting person. ${ }^{21}$ Similarly, it is submitted, if $B$ supplies $\mathrm{A}$ with a substance for administration to $\mathrm{V}$, believing that it will cause $\mathrm{V}$ minor discomfort and $\mathrm{A}$ administers it, knowing that it is a deadly poison. The substance is the same, but the administration of an emetic is fundamentally different from the administration of a deadly poison. ${ }^{22}$ In determining the nature of the act, the physical movements cannot be divorced from the circumstances in which they are done.

Stephen's Art 38 which I quoted earlier as saying that a party taking part in the execution of a common criminal purpose is a principal in the second degree in respect of every crime committed by any of the parties in the execution of the common purpose, goes on:

"If any of the offenders commits a crime foreign to the common criminal purpose, the others are neither principals in the second degree nor accessories unless they actually instigate or assist in its commission."

But what is a crime "foreign to the common criminal purpose"? It has always been the law that secondary parties were liable for some acts going

19 Today a full direction would have told the jury to consider whether, if $\mathrm{K}$ did not intend $\mathrm{M}$ deliberately to run down $\mathrm{V}$, he knew there was a real risk that he would do so.

$20 S v$ Robinson 1968 (1) SA 666.

${ }^{21} S v$ Robinson, supra.

22 1n the converse situation B is guilty of murder and A of manslaughter. A is a "semi innocent agent" and both are principals: Burke [1986] 1 All ER 833 at 839-40, Smith and Hogan, Criminal Law (8th ed, 1996), 153-155. 
beyond the common purpose. Foster wrote in his authoritative Crown $L a w^{23}$ in 1792, ".... whenever the principal goes beyond the terms of the solicitation, if in the event the felony committed was a probable consequence of what was ordered or advised, the person giving such orders or advice will be an accessory to that felony."

Stephen in Art 41 stated the law in similar terms and so did contemporary editions of Russell on Crime, applying the same rule to principals in the second degree. But, since the decision of the Privy Council in 1984 in Chan Wing-siu it has become clear that the law is less strict. It is not sufficient that the crime in question was a probable consequence of the crime intended - an objective test. It must be proved that the alleged secondary party foresaw that it might be committed by the principal. In two appeals heard together Powell and another and English, ${ }^{24}$ the House of Lords confirmed the principles of secondary liability, applicable in crimes generally, as stated in Chan Wing-siu. The characteristic of a joint enterprise is that the parties have a common purpose to commit an offence. It is not merely that each intends to commit the same offence; each is aware and supportive of the intention of the others. Proof of a common purpose imports that intention to assist or encourage the actual perpetrator which is the essence of secondary participation. No further evidence is necessary. It is appropriate to consider such cases separately.

(a) Where the parties have a common purpose to commit an offence (crime $X)$ -

(i) $\mathrm{B}$ is liable for the commission by $\mathrm{A}$ of that crime $(\mathrm{X})$ and

(ii) $\mathrm{B}$ is also liable for a crime (Y) which it was not their common purpose to commit if B knew that A might do - there was a real risk that he would do - an act of the kind which he did, and which resulted in crime (Y), while committing the crime $(\mathrm{X})$ which it was their common purpose to commit. In a recent article, ${ }^{25}$ simply to facilitate discussion, I have called the former "basic accessory liability" and the latter "parasitic accessory liability." A and B have the common purpose of committing burglary and B knows that there is a real risk that, in the course of committing the burglary envisaged, A might do an act with intent to cause grievous bodily harm. A does an act of the kind foreseen and kills. There was no common purpose to commit grievous bodily harm, but $\mathrm{B}$, whether present or absent, is guilty of murder. If $\mathrm{B}$ knows that, in the course of committing the burglary, A may act with intent to kill and A does so, both are guilty of attempted murder though there is no common purpose to commit murder. ${ }^{26}$

(iii) $\mathrm{B}$ is not liable for a crime $(\mathrm{Z})$ committed by $\mathrm{A}$ in the course of committing crime (X) if the relevant act done by A was of a materially different kind from any act foreseen by B. In English A and B both armed themselves with stakes to attack a constable. B knew that A might intentionally cause grievous bodily harm with a stake. If A had done so, B would have been liable to conviction under section 18 of the Offences against the Person Act 1861 and, if the constable had died, of murder. But A killed the officer with a knife which B did not know he had. In those circumstances, B was not guilty of murder, or of manslaughter, unless the jury was satisfied that the act causing death was not fundamentally

23 3rd ed. 1809, 370.

24 [1997] 4 All ER A5, [1998] Crim LR 48.

25 "Criminal Liability of Accessories: Law and Law Reform" (1997) 110 LQR, 453, 454-5

26 O’Brien [1995] Crim LR 734. 
different from any act which he envisaged when engaging or taking part in the joint enterprise. English's conviction was quashed because it was not left to the jury to decide. Both a stake and a knife may be used to cause grievous bodily harm; but a jury might think there is a fundamental difference, because a knife is so much more likely to kill. A person may well agree to take part in a joint enterprise involving the use of one, but not the use of the other.

The question whether B knew that A had a knife was of crucial importance in English as it has been in many similar cases. If B did not know that, he could hardly have foreseen an act of the kind that was done. But the fact that B knows that A has a particular weapon should not be regarded as conclusive of guilt when that weapon is used. Lord Hutton delivering the principal speech in English, applying the decision of Carswell $\mathrm{J}$, as the Lord Chief Justice then was, in Gamble, ${ }^{27}$ accepted that, if $A$ and B set out with the common purpose of "kneecapping" V with a shotgun (an act which will certainly amount to grievous bodily harm but is unlikely to cause death) and A produces a knife, which B did not know he had, and cuts V's throat, B is not liable for that unforeseen and fundamentally different act. But other decisions and dicta approved by the House suggest that if A were to use the shotgun, not to kneecap V, but to blow his brains out, B would be liable because he contemplated the use of a shotgun. The fact that the use of a particular weapon is contemplated may be a very important factor, but it should be no more than a factor, in deciding whether the act done is fundamentally different from any act contemplated by B; and, for example, the act of frightening, even with a loaded gun, is surely fundamentally different from firing the gun intending to kill.

Some cases decided before English must now, I think, be regarded as of doubtful authority. Stewart and Schofield is one. In Li and others ${ }^{28}$ five members of a Triad gang set out to take action against a man, E. Four of the gang intended to murder him by shooting but the fifth, $\mathrm{S}$, we must take it, believed that $\mathrm{E}$ was only to be frightened; but frightened by the firing of a loaded gun. E was murdered. S was convicted of manslaughter. The jury, having been properly directed on the law of murder, were not satisfied that he foresaw a real risk that the gun would be fired with intent to kill or cause grievous bodily harm. His conviction of manslaughter was upheld because he knew that a loaded gun might be fired. Shooting to kill was not, thought the court, a complete departure from the enterprise; but should not, at least, that have been left to the jury to decide? And could a jury reasonably find that shooting to kill is not fundamentally different from shooting to frighten? There is all the difference in the world from the point of view of the person at the wrong end of the gun.

English was valuably interpreted by the Court of Appeal in $U d d i n^{29}$ and in Greatrex. ${ }^{30}$ To take three of the important points.

(1) If the weapon used by A was different from, but as dangerous as, the weapon contemplated by B, B should not escape liability on that ground. In Greatrex it was held that it should have been left to the jury to decide whether kicking with "a shod foot," which was contemplated by $\mathrm{B}$, was fundamentally different from striking with a bar or spanner, which was what happened and was not contemplated by him.

\footnotetext{
27 [1989] NI 268.

28 (96/5461/W3, 25 /7/97, Crim App Office index supp., C-20).

29 [1998] 2 All ER 744.

30 [1999] 1 Cr App R 126.
} 
(2) If the injury inflicted by A was of an entirely different type from any contemplated by B, B was not liable. That seems to cover the case where $\mathrm{B}$ contemplates the use of the shotgun to kneecap $\mathrm{V}$ but $\mathrm{A}$ uses it to blow V's brains out.

(3) If the fatal act done by A was fundamentally different from any foreseen by B, B is not liable for murder or manslaughter. This point has been confirmed by Mitchell and King. ${ }^{31}$ Some critics disagree, and it means that several cases which have not been formally overruled are wrongly decided as in Li's case which I have discussed; but, in my opinion, it is right in principle. B cannot be guilty of homicide unless he was responsible for the act causing death, either by doing it or being an accessory to it.

(b) Where there is no common purpose.

The application of parasitic liability has been considered so far only in relation to joint enterprise cases - cases where there is a common purpose, whether planned or formed on the spur of the moment. Probably most accessory liability depends on the existence of a common purpose, but not all. B may give assistance or encouragement to A to commit an offence without in any way sharing his purpose to commit it. B may sell A equipment, knowing that $\mathrm{A}$ intends to use it to commit burglary, or a gun, knowing that A intends to use it to kill, being completely indifferent what A does and interested only in the profit to be made on the sale. ${ }^{32}$ Or B may give assistance to $\mathrm{A}$ of which $\mathrm{A}$ is unaware. Coming by chance upon $\mathrm{A}$ assaulting a constable, B trips up a second constable who was running to the aid of the first. Or, being told by A that he is going to commit a certain crime, B encourages him: "Good. Do that." 33 In all of these cases, $\mathrm{B}$ is liable for the crime which he knows $\mathrm{A}$ intends to and does commit. What if he knows that there is a real risk that, in the course of committing the intended crime, $\mathrm{P}$ will commit - and he does commit - some other more serious offence? A recent case suggests parasitic liability applies, at least to the aider.

In Reardon $^{34} \mathrm{~A}$ shot two men, $\mathrm{X}$ and $\mathrm{Y}$, in the bar of a public house and carried them, both dying, into the garden. He returned to the bar, said to B that one of them was still alive and asked B for the loan of his knife. B handed A a knife with a six inch blade which A took into the garden. Medical evidence established that both men would have died from the gunshot wounds but both in fact died from stab wounds inflicted with B's knife. B appealed against his conviction on two counts of murder. He argued that he had loaned the knife to kill only the one person whom he believed to be still alive. He relied on a passage in Smith and Hogan: ${ }^{35}$

"If [B] aids, abets, counsels or procures [A] to commit a crime against a particular person,... [B] is not liable if A intentionally commits an offence of the same type against some other person..."

The court did not dispute this proposition but held there was a further question (the Chan Wing-siu/English question):

No $9705605,24 / 7 / 98$.

32 National Coal Board v Gamble [1958] 3 All ER 203 at 209, per Devlin J.

33 This is enough, according to Giannetto [1997] 1 Cr App R 1 at 13, [1996] Crim LR 722.

34 No 9601499 Z4, 19 Feb 1998 (Beldam LJ, Johnson and Rix JJ)

35 Criminal Law (8th ed, 1996) 142. 
"Did [B] foresee at least the strong possibility that if [A] found that the other deceased was still breathing and alive, he might use the knife in the same way, and if he did so was that an act by [A] of a type which this appellant foresaw but did not necessarily intend?"

This was a jury question which, in the court's opinion, had been answered in the affirmative. If the jury had answered the question, no, there then would have been great force in B's submission ${ }^{36}$ that he could be convicted of neither murder. Certainly it was a case of both or neither, for there was no way of distinguishing between the victims. B did not know which murder he was aiding. If A had said, " $\mathrm{X}$ is still alive," $\mathrm{B}$ would certainly have been guilty of the murder of $X$, but not guilty of the murder of Y, unless the Chan Wing-siu question were answered in the affirmative. There is no suggestion of common purpose between A and B to kill either $\mathrm{X}$ or $\mathrm{Y}$. So the case decides that parasitic liability applies to the aider, even where there is no common purpose. The parasitic offence here was of the same gravity as the intended offence, but the principle is the same. If B had loaned $\mathrm{A}$ the knife for the purpose of threatening $\mathrm{V}$, knowing there was a real risk that $\mathrm{A}$ would use it to kill $\mathrm{V}$, and he did, it must follow logically that B would be guilty of murder.

If $\mathrm{B}$, when he trips up the officer coming to the aid of his colleague, $\mathrm{A}$, knows that A habitually carries a knife which he is likely to use against a policeman, B would seem to be liable for the wounding which follows and for murder if he knew there was risk that A would intentionally cause serious injury with the knife. It is at least possible then that parasitic liability is not confined to joint enterprise or common purpose cases but extends across the whole range of accessory liability.

There is a strongly held view that, even before Reardon, the law relating to the liability of the accessory stretched too far. This is a matter which will certainly engage the attention of the Law Commission when it returns to the subject. But reform of the law is a problem for another day.

\footnotetext{
36 Per Mr J Perry QC.
} 